\title{
Short Thought over Tax Issues
}

\section{Dear readers,}

at the close of 2011 I would like to spare a moment of thought over tax issues which have come up during the year.

The Czech Ministry of Finance has continued with the preparation of a single collection point, an intention which has been the subject of several years of acclaim and preparation. The aim of a single collection point is to unify the collection of taxes, social and health insurance to a single form, to a single authority. These intentions can adequately be termed using the word "tax reform". They are certainly attractive from the taxpayer's point of view (administration would decrease), but less so for numerous state officials. The result of these preparations was the presentation of the proposal of the Act to the House of Parliament, where it was shown to be incomplete, ill-conceived and impracticable. Thus the tax reform has been postponed to 2014 for the purposes of better preparation.

Across the border, the situation (as far as tax reforms are concerned) is not much better. In October 2011, Milan Chovan (the President of the Slovak Chamber of Tax Advisors) informed his Czech colleagues at the annual general meeting that Slovakia is preparing a major tax reform, the intention of which is (among others) the implementation of super gross salary in the Slovak Republic. Apparently, the Czech model had gained such favor among them that they were inspired by it and would like to implement it in the Slovak Republic. Roughly a month later, the Slovak government fell and all intentions connected with tax reforms were indefinitely shelved.

Let me one more remark in connection with super gross salary. Its abolition is among the intentions of the Ministry of Finance, as presented in the Czech tax reform. In the area of taxation of physical entities employers, however, we would not return to the state of affairs before its implementation (when insurance paid by the employer was deducted when calculating the tax base) but rather the tax base under the new concept would be comprised of gross salary minus non-taxable items. Thus we have yet another new model of taxation. The only people pleased 
by this novelty will be software companies (who will be the ones changing software for the calculation of salaries) and education agencies.

The Commission has presented a proposal for a financial transaction tax in the 27 Member States of the European Union. The tax would be levied on all transactions on financial instruments between financial institutions when at least one party of the transaction is located in the EU. The exchange of shares and bonds would be taxed at a rate of $0.1 \%$ and derivative contracts at a rate of $0.01 \%$. The Commission has proposed that the tax should come into effect from 1st January 2014.

The revenues of the tax would be shared between the EU and the Member States. Part of the tax would be used as an EU own resource which would partly reduce national contributions. Member States might decide to increase the part of the revenues by taxing financial transactions at a higher rate.

Algirdas Šemeta, Commissioner for Taxation, Customs, Anti-fraud and Audit, said: "With this proposal the European Union becomes a forerunner in the global implementation of a financial transaction tax. Our project is sound and workable. I have no doubt this tax can deliver what EU citizens expect; a fair contribution from the financial sector. I am confident that our partners in the G20 will see their interest in following this path."1

The financial transaction tax aims at taxing the $85 \%$ of financial transactions that take place between financial institutions. Citizens and businesses would not be taxed. House mortgages, bank loans, insurance contracts and other normal financial activities carried out by individuals or small businesses fall outside the scope of the proposal.

The decision followed an analysis of different tax instruments to make the financial sector contribute to the recovery of the EU economy. In parallel, the Commission has explored ways to introduce a financial transaction tax at global level since 2009 with its international partners in the G20.

EC: Commission Proposes a Financial Transaction Tax for Europe. [on-line],

Brussels, European Commission, c2011, [30 ${ }^{\text {th }}$ October, 2011],

$<$ http://ec.europa.eu/commission_2010-2014/semeta/headlines/news/2011/09/201109 28_en.htm>. 
A further activity of the European Commission aims towards the harmonization of direct taxes. In 2011, a proposal for a directive on a common consolidated corporate tax was presented. After several years' of discussion, material which would enable the implementation of a single, voluntary system of taxing legal entities was compiled. This would entail replacing 27 tax systems with a single one, but the introduction of a $28^{\text {th }}$ multi-national system for the taxation of income tax. Europe drew inspiration from USA and Canada. This theme is highly acute.

Dear readers, allow me in closing to wish you pleasant times during the festive season and all the best health and wishes for the New Year.

Ing. Jana Skálová, Ph.D.

Member of Editorial board European Financial and Accounting Journal 